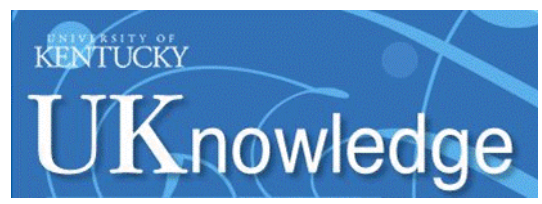

University of Kentucky

UKnowledge

$11-1994$

\title{
Correlates and Consequences of Early Initiation of Sexual Intercourse
}

Ann L. Coker

University of South Carolina - Columbia, ann.coker@uky.edu

Donna L. Richter

University of South Carolina - Columbia, drichter@mailbox.sc.edu

Robert F. Valois

University of South Carolina - Columbia, RFValois@mailbox.sc.edu

Robert E. McKeown

University of South Carolina - Columbia, rmckeown@sc.edu

Carol Z. Garrison

University of South Carolina - Columbia, cgarrison@uab.edu

Follow this and additional works at: https://uknowledge.uky.edu/crvaw_facpub See next page for additional authors

Part of the Female Urogenital Diseases and Pregnancy Complications Commons, Male Urogenital

Diseases Commons, Mental and Social Health Commons, Psychiatry and Psychology Commons, Public

Health Commons, Social Work Commons, and the Sociology Commons

Right click to open a feedback form in a new tab to let us know how this document benefits you.

\section{Repository Citation}

Coker, Ann L.; Richter, Donna L.; Valois, Robert F.; McKeown, Robert E.; Garrison, Carol Z.; and Vincent, Murray L., "Correlates and Consequences of Early Initiation of Sexual Intercourse" (1994). CRVAW Faculty Journal Articles. 104.

https://uknowledge.uky.edu/crvaw_facpub/104

This Article is brought to you for free and open access by the Center for Research on Violence Against Women at UKnowledge. It has been accepted for inclusion in CRVAW Faculty Journal Articles by an authorized administrator of UKnowledge. For more information, please contact UKnowledge@lsv.uky.edu. 


\section{Correlates and Consequences of Early Initiation of Sexual Intercourse}

Digital Object Identifier (DOI)

http://dx.doi.org/10.1111/j.1746-1561.1994.tb06208.x

Notes/Citation Information

Published in Journal of School Health, v. 64, no. 9, p. 372-377.

Dr. Ann Coker had not been a faculty member of the University of Kentucky at the time of publication.

Authors

Ann L. Coker, Donna L. Richter, Robert F. Valois, Robert E. McKeown, Carol Z. Garrison, and Murray L. Vincent 


\title{
Correlates and Consequences of Early Initiation of Sexual Intercourse
}

\author{
Ann L. Coker, Donna L. Richter, Robert F. Valois, \\ Robert E. McKeown, Carol Z. Garrison, Murray L. Vincent
}

\begin{abstract}
This cross-sectional analysis of the 1991 CDC Youth Risk Behavior Survey explored factors associated with an early age at first sexual intercourse. Almost $18 \%$ of White males, $49 \%$ of Black males, $5 \%$ of White females and $12 \%$ of Black females were sexualty active before age 13. Carrying a weapon to schoot, fighting, and earty (e age 13) expertmentation with cigarestes and alcohol were associated with early initiation of sexual activity for all four wice and gender groupings. Those initiating sexual activity early had greater numbers of partners but were $50 \%$ less likely to use condoms regularty and were two-seven times more likely to have been pregnant or caused a pregnancy. Females who initiated sexual activity early were more likely to have had a sexually transnitted disease (STD). Interventions to postpone sexual activity need to be tailored to the ethnic and gender differences observed in these analyses. Interventions must begin before age 13 and should be comprehensive school-based efforts. (J Sch Health. 1994;64(9):372-377)
\end{abstract}

$\mathbf{F}$ or the past two decades, sexual intercourse among U.S. adolescents has resulted in increases both in sexually transmitted diseases (STDs) and unintended pregnancies. ${ }^{.}$ A greater proportion of adolescent females are sexually active today than in the past, and age at first intercourse is dropping. ${ }^{2}$ Early age at first intercourse is associated with an increased number of sex partners, a greater risk for STDs, ${ }^{3}$ and an increased risk for cervical neoplasia. ${ }^{4}$ Pregnancies occurring among school-age females result primarily from adult male/teen-age female intercourse; seven in 10 births to teen-age women were fathered by men older than age $20 .{ }^{5}$ Negative effects from early parenthood have been amply documented. Health, education, and future employment are adversely affected; poverty is a frequent outcome. ${ }^{6}$

Almost two-thirds of STDs diagnosed in 1990 in the U.S. occurred among persons younger than age $25{ }^{7}$ The presence of genital lesions caused by STD also can enhance the possibility of human immunodeficiency virus (HIV) transmission during intercourse. Correct use of condoms during sexual intercourse would offer a degree of protection against STDs, including HIV, but nationally, less than half of sexually active high school adolescents reported using a condom at last intercourse. ${ }^{8}$

This article estimates the frequency of self-reported early sexual intercourse (< age 13) in a statewide, community-based sample of public high school students. Rates of early sexual intercourse among Black and White males and females are compared. Behavioral and demographic factors associated with early sexual initiation, by race and

Ann L. Coker; PhD, Assistant Professor; Robert E. McKeown, PhD, Assistant Professor; and Carol Z. Garrison, PhD, Professor and Chair; Dept. of Epidemiology and Biostatistics; and Donna L. Richter; EdD. Associate Professor; Robert F. Valois, PhD, MPH, Associate Professor; and Murray L. Vincent, EdD, Professor; Dept. of Health Promotion and Education, School of Public Health. University of South Carolina, Columbia, SC 29208. This research was funded by Cooperative Agreement HU63/CCU 802750-03, Division of Adolescent and School Health, National Center for Disease Prevention and Health Promotion, Centers for Disease Control and Prevention, Atlanta, Ga., and Cooperative Agreement with the South Carolina Dept. of Education. This article was submitted June 28, 1994, and accepted for publication September 19, 1994. gender, also are explored. This information can help target higher risk groups for earlier sexuality education and to assist health educators in tailoring educational messages to those at increased risk of early sexual activity.

\section{Sample}

\section{METHODS}

The Youth Risk Behavior Survey (YRBS), a statewide survey of public school students in grades 9-12, was conducted February-May 1991 in South Carolina. All public high schools, except for special education institutions, with grade nine or above were eligible for selection. The initial sampling frame included 207 schools stratified into three levels based on enrollment: large $(1,285-2,577)$, medium (887-1,278), and small (74-874). Each level subsequently was rank ordered according to minority racial composition. Within levels, schools were selected systematically with probabilities proportional to enrollment size across strata using a random start, and 69 schools were selected PCSAMPLE ${ }^{9}$ developed by WESTAT. All schools selected for sampling were recruited by contacting their district superintendent. Of 43 districts contacted, 32 districts representing 49 individual schools agreed to participate.

Each school provided its second period class lists which were sequentially numbered. Self-weighting random number worksheets generated by PCSAMPLE selected classes from the roster of classe eligible to receive the survey. As each eligible class was added to the sample list, the enrollment was cumulatively totaled. Classes no longer were added to the sample when within $10 \%$ of the enrollment needed. When the number of sampled students was substantially less than expected, the sample was augmented with systematic samples of additional classes.

\section{Instrumentation}

Data were collected using a modified version (questions were added) of the self-report Youth Risk Behavior Survey developed and piloted by the Centers for Disease Control and Prevention. The questionnaire focused on high-risk, health-promoting behavior and demographics 
relevant to high school students, including sexual behavior (age at first sexual intercourse, number of sexual partners), aggressive behavior (carrying weapons, fighting, suicide ideation); cigarette, chewing tobacco, illicit drug, alcohol, and steroid use; exercise and diet; body-size perception; television/video viewing; academic self-image; eligibility for free lunch, adults the adolescent lives with, frequency of attendance at religious services; and demographic indicators (gender, race, grade in school, and age).

Information on sexual behavior was collected in the following questions: (a) Have you ever had sexual intercourse? (b) How old were you when you had sexual intercourse for the first time? (c) During your life, with how many people have you had sexual intercourse? and (d) During the past three months, with how many people did you have sexual intercourse? An early age at first sexual intercourse was defined as beginning sexual activity when younger than age 13 . Four mutually exclusive categories of age at first sexual intercourse were created: those beginning sexual activity when (a) younger than age 13, (b) age 13-14, (c) age 15+, and (d) those who never had sexual intercourse (virgins). High school students younger than age 14 were excluded from the analysis. Factors potentially associated with beginning sexual activity at an early age $(<$ age 13$)$ were divided conceptually into (a) risk factors for early sexual activity and (b) factors which were a consequence of early sexual activity.

\section{Risk Factors for Early Initiation of Sexual Intercourse}

Polychotomous logistic regression analyses were performed to explore the relation between demographic and other risk variables and beginning sexual intercourse when age 13 or younger. Analyses were conducted within race and gender specific strata. Analyses which assessed risk factors for early initiation of sexual activity included all subjects (virgins and non-virgins). Categories for age when beginning to engage in sexual intercourse were as follows: $<13,13-14,15+$, and virgins. Three sets of odds ratios for each risk factor category of interest resulted: odds ratio comparing (a) early initiation when less than 13 with virgins, (b) initiation when 13-14 with virgins, and (c) initiation when 15-18 years with virgins. The following risk factors were assessed: age at participation in the study, self-image of academic ability, carrying weapons to school, cigarette smoking, alcohol use, chewing tobacco (males), steroid use (males), whether parents talk to the adolescent about HIV/AIDS, the adolescents' selfperception of body size, adults with whom the adolescent lives, the adolescents' frequency of religious service attendance, and the adolescents' eligibility for free lunches.

Analysis of early initiation of sexual activity was conducted only among sexually active adolescents. Again, logistic regression models estimated the relationship between beginning sexual activity when younger than age 13 and the following list of outcomes by race and gender specific strata: total number of sexual partners, number of partners in the past three months, use of alcohol or drugs when the adolescent last had sexual intercourse, use of condoms when the adolescent last had sexual intercourse, whether the adolescent had ever become preg- nant or caused a pregnancy, and whether the adolescent had any STDs. Adjusted odds ratio estimates compared (a) those beginning sexual activity when younger than age 13 with those delaying sexual activity $(>15)$ and $(b)$ those beginning sexual activity when 13-14 with those delaying until age 15 or later.

\section{RESULTS \\ Early Initiation of Sexual Activity by Race and Gender}

Table 1 presents the cumulative frequency of age at first sexual intercourse by race and gender groups. Almost $18 \%$ of White males reported having sexual intercourse before age 13 , while $49 \%$ of Black males were sexually active before age 13 . Only $5 \%$ of White females were sexually active before age 13 , compared to $12 \%$ of Black females. Thirty-eight percent of White males were virgins at the time of the interview compared to $47 \%$ of White females, $12 \%$ of Black males and $27 \%$ of Black females.

Table 2 indicates that males were 6.8 times more likely than females to have begun sexual intercourse when younger than age 13 when controlling for race. Males were $60 \%$ more likely to report beginning sexual activity when ages 13-14 yet were no more likely to begin sexual activity at ages 15-18 compared to females. This trend toward males being more likely to begin sexual intercourse at earlier ages than females was statistically significant $(p<$ 0.001 ). Adjusting for gender, Black adolescents were 6.9 times more likely than White adolescents to have begun having sexual intercourse by age 13, three times more likely to begin during ages 13-14, and two times more likely than Whites to begin between ages 15-18. This trend toward Black adolescents being more likely to begin sexual activity at earlier ages than White adolescents also was statistically significant $(p<0.001)$. Because race and gender were associated so strongly with age at first sexual. intercourse, the subsequent analysis characterizing risk factors and consequences of an early age at first sexual intercourse were conducted within the four strata of race and gender groupings: White males, Black males, White females, and Black females.

\section{Behavioral and Demographic Factors by Race and Gender}

Distribution of demographic risk factors by race and gender are presented in Table 3. A total of 5,478 students was included in these analyses: 1,509 White males, 1,234 Black males, 1,479 White females, and 1,256 Black females. The age distribution is comparable across the four race and gender groupings, with the exception that Black males were slightly older than the other race/gender groups. Blacks were twice as likely as Whites to rank themselves as being among the best students in their class compared with Whites. White females were least likely of the race/gender groups to rank themselves among the best students in their class: $15.6 \%$ of White females ranked themselves among the best compared with $25 \%$ of all students.

Approximately $25 \%$ of the entire sample reported never attending religious services. Females were more likely 
than males to report attending regularly (three or more times per month), and Black females were most likely to attend religious services. A striking racial difference in reported eligibility for free lunches was observed. Blacks were 6.2 times more likely than Whites to report being eligible for free lunches: $8.4 \%$ of Whites were eligible compared with $52.1 \%$ of Blacks. Most students lived with both parents: $64 \%$ of Whites and $43 \%$ of Blacks. Blacks, however, were significantly more likely than Whites not to live with either parent.

Almost $33 \%$ of males and $25 \%$ of females began drinking alcohol before age 13 . White adolescents were more than twice as likely as Black adolescents to begin smok-

Table 1

Cumulative Frequency of Age at First Sexual Intercourse by Race and Gender Groups, Youth Behavioral Risk Survey, 1991, South Carolina

\begin{tabular}{llll}
\hline Males & \multicolumn{3}{c}{ Females } \\
\hline Whlte & Black & White & Black \\
$(N=1,509)$ & $(N=1,234)$ & $(N=1,479)$ & $(N \div 1,256)$
\end{tabular}

Age at first sexual intercourse (Cumulative \%)

\begin{tabular}{lcccc}
\hline Before age 13 & $17.8 \%$ & $49.2 \%$ & $5.1 \%$ & $11.9 \%$ \\
\hline By age 13-14 & $40.9 \%$ & $74.2 \%$ & $23.6 \%$ & $40.9 \%$ \\
\hline By age 15-18 & $62.0 \%$ & $87.8 \%$ & $52.9 \%$ & $73.2 \%$ \\
\hline $\begin{array}{l}\text { Virgin at the time of study } \\
\text { participation }\end{array}$ & $38.0 \%$ & $12.2 \%$ & $47.1 \%$ & $26.8 \%$ \\
\hline
\end{tabular}

Table 2

Adjusted Odds Ratio ( $\& 95 \% \mathrm{Cl}$ ) for Age at First Intercourse by Race and Gender

\begin{tabular}{lllll}
\hline Age at First Intercourse & \multicolumn{2}{l}{ Males versus Females* } & \multicolumn{2}{l}{ Blacks versus Whites** } \\
\hline$<13$ years & 6.8 & $(5.6-8.2)$ & 6.9 & $(5.8-8.2)$ \\
\hline $13-14$ years & 1.6 & $(1.4-1.9)$ & 3.0 & $(2.5-3.5)$ \\
\hline $15+$ years & 0.9 & $(0.8-1.0)$ & 2.0 & $(1.7-2.3)$ \\
\hline
\end{tabular}

*Gender adjusted for race, * *Race adjusted for gender

Table 3

Distribution of Demographic Risk Factors by Gender and Race

\begin{tabular}{lcccc}
\hline & \multicolumn{2}{c}{ Males } & \multicolumn{2}{c}{ Fomales } \\
\cline { 2 - 5 } Risk Factor & $\begin{array}{c}\text { White } \\
(\mathrm{N}=1,509)\end{array}$ & $\begin{array}{c}\text { Black } \\
(\mathrm{N}=1,234)\end{array}$ & $\begin{array}{c}\text { White } \\
(\mathrm{N}=1,479)\end{array}$ & $\begin{array}{c}\text { Black } \\
(\mathrm{N}=1,256)\end{array}$ \\
\hline Mean age (S0) & $16.1(1.2)$ & $16.4(1.2)$ & $15.9(1.2)$ & $16.2(1.2)$ \\
\hline Academically best in class & $20.3 \%$ & $31.1 \%$ & $15.6 \%$ & $30.7 \%$ \\
\hline Never attends church & $27.2 \%$ & $23.1 \%$ & $24.0 \%$ & $13.4 \%$ \\
\hline Eligible for free lunch & $9.9 \%$ & $47.3 \%$ & $6.9 \%$ & $56.8 \%$ \\
\hline Lives with both parents & $64.1 \%$ & $46.0 \%$ & $63.9 \%$ & $40.0 \%$ \\
\hline $\begin{array}{l}\text { Drank alcohol } \\
\text { before age 13 }\end{array}$ & 39.0 & $30.6 \%$ & $25.8 \%$ & $23.9 \%$ \\
\hline Smoked before age 13 & $11.6 \%$ & $5.3 \%$ & $9.5 \%$ & $3.0 \%$ \\
\hline Got into a fight at school & $51.1 \%$ & $47.0 \%$ & $30.7 \%$ & $33.7 \%$ \\
\hline $\begin{array}{l}\text { Brought weapons to } \\
\text { school }\end{array}$ & $54.8 \%$ & $39.3 \%$ & $9.5 \%$ & $16.9 \%$ \\
\hline
\end{tabular}

ing before age 13: approximately $10 \%$ of White adolescents and $4 \%$ of Black adolescents began smoking cigarettes before age 13. Almost half of male adolescents got in fights at school compared with one-third of females. Almost $55 \%$ of White male adolescents reported carrying a weapon to school compared to $40 \%$ of Black males, $10 \%$ of White females, and $17 \%$ of Black females.

\section{Correlates of Early Sexual Initiation by Race and Gender}

Table 4 presents the analyses investigating correlates of beginning sexual activity at an early age. Three risk categories of early initiation of sexual activity $(<13,13$ 14 , and 15+) were compared with virgins; three sets of odds ratios are presented. These analyses also are presented by the four race and gender groupings. The race and gender stratum specific odds ratios are adjusted for age, church attendance, free lunch eligibility, and number of parents with whom the adolescent lives. Significant associations are denoted with an asterisk (*).

The following factors consistently were associated with an early age at first sexual intercourse across all race and gender groups: carrying a weapon to school in the past month, getting into physical fights in the past year, beginning to smoke cigarettes, and an early age ( $<13$ years $)$ at first alcohol use. Thinking seriously about suicide correlated with an early age at first intercourse for all but Black males. The age at which adolescents began smoking cigarettes (compared with never smoking) was associated strongly with an early age at first intercourse for all but Black males. Using chewing tobacco was correlated with an early age at first intercourse for White males only, while steroid use was associated with an early age at first intercourse for Black and White males.

Self-perceived academic standing as best in their class was associated with a reduced risk of beginning sexual intercourse at an early age for White males only. For White females, academic standing being at or below the middle of the class was associated with an increased likelihood of beginning sexual activity when younger than age 13 . The adolescents' report of whether parents talked with them about HIV/AIDS, among those living with a parent, was not associated with an early age at first intercourse. Self-perception of being overweight was associated with a reduced risk of beginning sexual activity when younger than age 13 for Black males only. Never attending church was associated with an increased risk of an early age at first intercourse for Whites but not for Blacks. Living with an adult who is not a parent was associated strongly with risk of beginning sexual activity when younger than age 13 for all race and gender groupings except Black females. Finally, being eligible for free lunch was associated with an early age at first intercourse for Black females only.

A significant trend of increasing earlier age at sexual initiation and the following risk factors were noted for all race and gender groups with the exceptions noted: carrying a weapon to school, fighting, ever smoking cigarettes (except for Black males), beginning smoking when younger than age 13 (Whites only), beginning to drink alcohol when younger than age 13 , steroid use (males only), and never attending church (Whites only). 


\section{Consequences of Early Sexual Initiation by Race and Gender}

Table 5 presents the relation between factors which may be viewed as consequences of beginning sexual activity at an early age. Two risk categories, those beginning sexual activity when younger than age 13 and those beginning between ages 13-14, were compared with those beginning sexual activity when age 15 or older. Virgins were excluded from these analyses.

Beginning sexual activity early $(<13)$ was strongly associated with increasing numbers of lifetime sexual partners. Although beginning sexual activity when age 13-14 also was associated with increasing numbers of sexual partners, magnitude of the odds ratios was smaller than for those comparing adolescents beginning sexual activity when younger than age 13 . Depending on race and gender grouping, those beginning sexual activity when younger than age 13 were 9 (Black males) to 15 (White - lales) times more likely to have four or more sexual partners than were those beginning sexual intercourse when 15 or older. After controlling for lifetime number of sexual partners, an early age at first intercourse was not associated significantly with having two or more sexual partners in the past three months for any race/gender group.

An early age at first intercourse was associated with a two-fold increase in the odds of reporting use of alcohol and drugs at last sexual activity for all race/gender groups except White females. Beginning sexual activity when 13-14 (compared with 15+) was not associated with alcohol/drug use during the last sexual contact except for Black females. Those beginning sexual intercourse at an early age were only half as likely to have used condoms when they last had sex, compared with those delaying first intercourse (15+ years), across all race and gender groupings. Females who began sexual activity before age 13 were 3 (White females) to 4.5 times (Black females) more likely to report having become pregnant while in high school compared with those delaying sexual activity ( $15+$ years). Males beginning sexual activity early were almost twice as likely as delayers to report causing a pregnancy. Females who began sexual activity at an early age were more likely to report having had an STD compared

Correlates of an Early Age at First Intercourse Compared with those Delaying Sexual Initiation by Race and Gender

Adjusted Odds Ratios

\begin{tabular}{cc}
\hline \multicolumn{2}{c}{ Males } \\
\hline White Bemales
\end{tabular}

Risk Factor by Age at First Intercourse White Black White Black

\begin{tabular}{|c|c|c|c|c|}
\hline \multicolumn{5}{|c|}{ Carried weapon to school in last month: Yes/No' } \\
\hline$<13$ years compared with virgins & $2.8^{*}$ & $2.6^{*}$ & $5.3^{*}$ & $4.8^{\circ}$ \\
\hline $13-14$ years compared with virgins & $3.1^{\circ}$ & $2.1^{*}$ & $2.9^{*}$ & $4.1^{*}$ \\
\hline $15+$ years compared with virgins & $1.8^{*}$ & 1.5 & $1.9^{*}$ & $2.5^{*}$ \\
\hline \multicolumn{5}{|l|}{ Physical Fight in the last years: Yes/ $\mathrm{No}^{\prime}$} \\
\hline$<13$ years compared with virgins & $3.9^{\circ}$ & $2.6^{*}$ & $6.2^{\circ}$ & $2.1^{\circ}$ \\
\hline 13-14 years compared with virgins & $3.8^{\circ}$ & $2.0^{\circ}$ & $2.9^{\circ}$ & $2.2^{\circ}$ \\
\hline $15+$ years compared with virgins & $2.0^{*}$ & 1.3 & $2.4^{*}$ & $1.6^{*}$ \\
\hline \multicolumn{5}{|l|}{ Child ever thought seripusly about suicide' } \\
\hline$<13$ years compared with virgins & $2.4^{*}$ & 1.0 & $2.6^{*}$ & $2.0^{\circ}$ \\
\hline $13-14$ years compared with virgins & $1.9^{*}$ & 0.9 & $2.1^{*}$ & $1.6^{\circ}$ \\
\hline $15+$ years compared with virgins & $2.0^{*}$ & 1.0 & $2.3^{*}$ & $1.8^{*}$ \\
\hline \multicolumn{5}{|l|}{ Tried smoking cigaretts: Ever/Never' } \\
\hline$<13$ years compared with virgins & $4.1^{*}$ & $2.9^{*}$ & $14.9^{*}$ & $4.9^{*}$ \\
\hline $13-14$ years compared with virgins & $4.2^{\circ}$ & $2.7^{\circ}$ & $6.8^{*}$ & 4. $1^{\circ}$ \\
\hline $15+$ years compared with virgins & $2.3^{*}$ & $2.8^{\circ}$ & $4.1^{*}$ & $2.2^{\circ}$ \\
\hline
\end{tabular}

Began smoking when < 13 years'

\begin{tabular}{|c|c|c|c|c|}
\hline $\begin{array}{l}<13 \text { years compared with virgins } \\
13-14 \text { years compared with virgins } \\
15+\text { years compared with virgins }\end{array}$ & $\begin{array}{l}11.9^{*} \\
5.8^{*} \\
1.5\end{array}$ & $\begin{array}{l}2.1 \\
1.4 \\
\mathrm{NE}\end{array}$ & $\begin{array}{l}11.8^{*} \\
4.8^{\circ} \\
1.8^{\circ}\end{array}$ & $\begin{array}{l}2.0 \\
1.5 \\
1.6\end{array}$ \\
\hline \multicolumn{5}{|l|}{ Began drinking alcohol when $<13^{\prime}$} \\
\hline $\begin{array}{l}<13 \text { years compared with virgins } \\
13-14 \text { years compared with virgins } \\
15+\text { years compared with virgins }\end{array}$ & $\begin{array}{l}4.8^{*} \\
2.3^{*} \\
1.3\end{array}$ & $\begin{array}{l}2.4^{*} \\
1.1 \\
1.1\end{array}$ & $\begin{array}{l}6.8^{*} \\
2.5^{*} \\
1.6^{*}\end{array}$ & $\begin{array}{l}2.6^{*} \\
1.5^{*} \\
1.0\end{array}$ \\
\hline \multicolumn{5}{|l|}{ Used chewing tobaco: Ever/Never" } \\
\hline $\begin{array}{l}<13 \text { years compared with virgins } \\
13-14 \text { years compared with virgins } \\
15+\text { years compared with virgins }\end{array}$ & $\begin{array}{l}3.3^{*} \\
2.6^{*} \\
2.6^{*}\end{array}$ & $\begin{array}{l}0.8 \\
0.5 \\
0.5\end{array}$ & & \\
\hline
\end{tabular}

\begin{tabular}{lll}
\hline Used steroids: Ever/Never ${ }^{1}$ & & \\
\hline$<13$ years compared with virgins & $7.8^{*}$ & $3.2^{*}$ \\
$13-14$ years compared with virgins & $5.5^{*}$ & $2.6^{*}$ \\
$15+$ years compared with virgins & $2.5^{*}$ & 1.3
\end{tabular}

Self-ranked as one of the best students in the class'

\begin{tabular}{cllll}
\hline$<13$ years compared with virgins & 1.2 & 1.1 & $0.6^{*}$ & 0.8 \\
$13-14$ years compared with virgins & $0.7^{*}$ & 1.3 & $0.5^{*}$ & $0.7^{*}$ \\
$15+$ years compared with virgins & 0.8 & 0.7 & $0.6^{*}$ & 0.7
\end{tabular}

Parents talk with child about HIV/AIDS' (among those living with at least one parent)

\begin{tabular}{clllll}
\hline < 13 years compared with virgins & 0.9 & 1.2 & 1.1 & $0.7^{*}$ \\
$13-14$ years compared with virgins & 0.9 & 1.4 & 0.9 & 0.8 \\
$15+$ years compared with virgins & 0.9 & 1.2 & 1.0 & $0.7^{*}$ \\
\hline Self perception of being over-weight' & & & & \\
\hline & & & & \\
\hline < 13 years compared with virgins & $0.7^{\star}$ & $0.5^{*}$ & 1.3 & $1.7^{*}$ \\
$13-14$ years compared with virgins & 0.8 & $0.5^{*}$ & 1.2 & 1.1 \\
$15+$ years compared with virgins & 0.8 & 0.5 & 0.8 & 1.0
\end{tabular}

Frequency of religious services attendance: Never versus at least once a month ${ }^{3}$

$\begin{array}{lllll}<13 \text { years compared with virgins } & 2.3^{*} & 1.1 & 4.2^{*} & 1.2 \\ 13-14 \text { years compared with virgins } & 1 . \mathrm{B}^{*} & 1.1 & 2.9 & 1.3 \\ 15 \text { years compared with virgins } & 1.3 & 0.8 & 2.0 & 1.1\end{array}$

Lives with an adult, not a parent, versus living with parents ${ }^{2}$

\begin{tabular}{cllll}
\hline$<13$ yoars compared with virgins & $2.8^{*}$ & $2.6^{*}$ & $5.6^{*}$ & 1.0 \\
$13-14$ years compared with virgins & $5.0^{*}$ & $3.1^{*}$ & $3.1^{*}$ & 1.1 \\
$15+$ years compared with virgins & 1.3 & 1.8 & $2.5^{*}$ & 1.5 \\
\hline
\end{tabular}

Elıgible for free or reduced lunch: Yes $/ \mathrm{NO}^{4}$

\begin{tabular}{lllll}
\hline$<13$ years compared with virgins & $2.1^{*}$ & 1.4 & $2.3^{*}$ & $1.6^{*}$ \\
$13-14$ years compared with virgins & 1.2 & 1.2 & 0.7 & 1.2 \\
$15+$ years compared with virgins & 1.0 & 1.0 & 1.0 & 1.4 \\
\hline
\end{tabular}

${ }^{*} p \leq 0.005$

'Adjusted for age, religious service attendance, free lunch eligibility, and parents in household

${ }^{2}$ Adjusted for age, religious service attendance, and free lunch eligibility

${ }^{3}$ Adjusted for age, tree lunch eligibility, and parents in household

${ }^{4}$ Adjusted for age, religious service attendance, and parents in household

${ }^{\star *} p \leq 0.06$ 
to those who delayed sexual activity, yet males were no more likely to report having an STD if they had begun sexual activity early.

\section{DISCUSSION}

Several factors correlated significantly with early age at first sexual intercourse. Aggression, such as carrying a weapon to school and getting into a physical fight, was consistently associated with early sexual activity for all race and gender groups. Suicidal ideation also was associated with an early age at first intercourse for all but Black males. This observation raises concern because aggression and violence may be linked with sexual expression in the minds of teens. Additionally behavioral/ emotional problems may underlie aggressive behaviors and sexual inappropriateness.

Early experimentation (when younger than age 13) with alcohol and cigarettes was strongly associated with an early age at first intercourse for Whites, yet not consistently so for Blacks. Similarly, having ever used chewing tobacco or steroids associated strongly with an early age at first intercourse among White but not Black males. However, having ever tried to smoke cigarettes was associated with an increased probability of beginning sexual activity early. Therefore, experimentation with cigarettes may be the best risk indicator for beginning sexual activity early.

Demographic factors (eligibility for free lunch, whether

Table 5

Consequences of Early Age at First Intercourse by Race and Gender

\begin{tabular}{|c|c|c|c|c|}
\hline \multirow[b]{3}{*}{ Consequences by Age at First Intercourse } & \multicolumn{4}{|c|}{ Adjusted 0dds Ratios } \\
\hline & \multicolumn{2}{|c|}{ Males } & \multicolumn{2}{|c|}{ Females } \\
\hline & $\begin{array}{l}\text { White } \\
(N=874)\end{array}$ & $\begin{array}{l}\text { Black } \\
(\mathbb{N}=977)\end{array}$ & $\begin{array}{l}\text { White } \\
(N=756)\end{array}$ & $\begin{array}{l}\text { Black } \\
(N=856)\end{array}$ \\
\hline \multicolumn{5}{|l|}{$\geq 4$ lifetime sex partners versus $<4$ partners ${ }^{\prime}$} \\
\hline $\begin{array}{l}\text { Age }<13 \text { at first sex compared with } 15+1 \\
\text { Age } 13-14\end{array}$ & $\begin{array}{r}15.0^{*} \\
6.2^{*}\end{array}$ & $\begin{array}{l}9.0^{\star} \\
4.3^{\star}\end{array}$ & $\begin{array}{l}14.0^{\star} \\
6.1^{\star}\end{array}$ & $\begin{array}{r}10.9^{\star} \\
3.4^{\star}\end{array}$ \\
\hline \multicolumn{5}{|c|}{$\geq 2$ sex partners in the last 3 months versus $<2^{2}$} \\
\hline $\begin{array}{l}\text { Age }<13 \text { at first sex compared with } 15+ \\
\text { Age } 13-14\end{array}$ & $\begin{array}{l}1.1 \\
0.7\end{array}$ & $\begin{array}{l}1.5 \\
1.4\end{array}$ & $\begin{array}{l}1.2 \\
0.8\end{array}$ & $\begin{array}{l}1.0 \\
1.0\end{array}$ \\
\hline \multicolumn{5}{|c|}{ Alcohol/drugs used when last had sex: Yes/ $\mathrm{No}^{\prime \prime}$} \\
\hline $\begin{array}{l}\text { Age }<13 \text { at first sex compared with } 15+ \\
\text { Age } 13-14\end{array}$ & $\begin{array}{l}1.9^{*} \\
1.2\end{array}$ & $\begin{array}{l}1.8^{*} \\
1.4\end{array}$ & $\begin{array}{l}1.3 \\
1.2\end{array}$ & $\begin{array}{l}2.2^{\star} \\
2.7^{\star}\end{array}$ \\
\hline \multicolumn{5}{|l|}{ Condom used when last had sex: Yes/ $\mathrm{NO}^{4}$} \\
\hline $\begin{array}{l}\text { Age }<13 \text { at first sex compared with } 15+ \\
\text { Age } 13-14\end{array}$ & $\begin{array}{l}0.6^{\circ} \\
0.9\end{array}$ & $\begin{array}{l}0.6^{*} \\
1.1\end{array}$ & $\begin{array}{l}0.4^{*} \\
0.5^{\circ}\end{array}$ & $\begin{array}{l}0.5^{*} \\
0.7^{*}\end{array}$ \\
\hline \multicolumn{5}{|l|}{ Pregnant or caused pregnancy: Ever/Never' } \\
\hline $\begin{array}{l}\text { Age }<13 \text { at first sex compared with } 15+ \\
\text { Age } 13-14\end{array}$ & $\begin{array}{l}2.9^{\star} \\
1.5^{\star}\end{array}$ & $\begin{array}{l}1.8^{*} \\
1.2\end{array}$ & $\begin{array}{l}4.5^{*} \\
1.7^{\star}\end{array}$ & $\begin{array}{l}1.7^{\star} \\
1.5\end{array}$ \\
\hline \multicolumn{5}{|l|}{ Had sexually transmitted disease: Ever/Never' } \\
\hline $\begin{array}{l}\text { Age }<13 \text { at first sex compared with } 15+ \\
\text { Age } 13-14\end{array}$ & $\begin{array}{l}0.8 \\
0.9\end{array}$ & $\begin{array}{l}1.5 \\
1.7\end{array}$ & $\begin{array}{l}5.7^{\star} \\
2.0\end{array}$ & $\begin{array}{l}2.6^{\star} \\
1.8^{*}\end{array}$ \\
\hline \multicolumn{5}{|c|}{$\begin{array}{l}\text { "p<0.05 } \\
\text { 'Adjusted for age, religious service attendance, free lunch eligibility, and parents } \\
\text { living in the same household } \\
{ }^{2} \text { Adjusted for age, religious service attendance, free lunch eligibility, parents living in } \\
\text { the same household, and life-time number of sexual partners }\end{array}$} \\
\hline
\end{tabular}

the adolescent lives with a parent, and religious service attendance) were not associated consistently with an early age at first intercourse across all race and gender groups. Further, these factors are not ones which can easily be altered and, thus, are not prime candidates for schoolbased intervention programs. However, those not living with either parent can be seen as "at risk" of early sexual activity and could be targeted for specific risk-reduction programs.

Aggressive behaviors (fighting/carrying weapons) and substance use correlated with early sexual activity in this study. These relationships have been documented in other studies involving adolescents ${ }^{10-12}$ and support the theory that adolescent risk behaviors tend to cluster. ${ }^{13,14}$

From these data, it is clear that a large proportion of Black males (almost $50 \%$ ) report being sexually active before age 13. Adolescents may have over-estimated this proportion given social pressure to be sexually active ${ }^{15,16}$ yet regardless of whether this number is accurate, it is clear that Black male adolescents did report this level of activity and, thus, must place value on early sexual activity. Changing this attitude/perception that early sexual activity is valuable would be an important undertaking for school health initiatives. The finding of marked differences in the proportion of adolescents who begin sexually activity early by race and gender groups suggests the need to target sexuality education messages earlier for Blacks and males than for Whites and females. Sexuality education must occur before age 10 for Black males because $50 \%$ are sexually active by age 13 .

From these data, clear consequences of early sexual activity emerge. Those beginning sexual activity early are at least 10 times more likely to have greater numbers of sexual partners. Increased numbers of sexual partners place adolescents at increased risk for a range of STDs including HIV/AIDS. From these data, females who began sexual activity at an early age were three-six times more likely to report having had an STD than those who delayed sexual activity. Further, those beginning sexual activity earlier are half as likely to engage in safersex and twice as likely to have been pregnant or caused a pregnancy.

\section{CONCLUSION}

These data suggest that many adolescents are sexually active early in life. Young males in particular may face significant peer pressure to become sexually active early. ${ }^{15.16}$ Intervention strategies to prevent teen-age pregnancy and STDs including HIV must be tailored to the population served and its special needs. The need to include STD and HIV prevention within a comprehensive health education curriculum is particularly acute in light of adolescents' lack of perceived vulnerability.

School-based health instruction programs are most likely to help reduce risk behavior when placed within the context of a comprehensive school health education curriculum, and when they provide information and skills relevant to the adolescents' actual lifestyles. ${ }^{17,18}$ Ideally, risk reduction education provided in a comprehensive school health education curriculum should address five elements of personal behavior in their relevant social contexts: 1) rational element: providing facts about STDS, 
the emotional element: assisting students to acknowledge vulnerability to infection and commit to risk-reduction behavior, 3) practical element: teaching students to develop personal skills to achieve desired behaviors (communication, negotiation, and refusal skills which help students say "no" and keep their friends), 4) interpersonal element: developing social networks for knowledge, emotional development, and skills to reinforce healthful behavior change (smoking cessation and aggression alternatives support groups), and 5) structural element: providing access to supplies (condoms, safer sex literature) and services (STD clinic services, substance abuse counseling and treatment) instrumental in supporting behavior change to reduce risk. ${ }^{3.19}$

Classroom curricula should be supplemented by other school-wide programs, such as peer programs, individual counseling, theatrical presentations, and media events, These combined school-based efforts also should be linked with health and reproductive care services within the school and community. ${ }^{20}$ In addition, parents, youthserving organizations, religious institutions, health care professionals, the government, and media can share in reality-based sexuality education for adolescents. ${ }^{21}$

Dr. Jocelyn Elders, U.S. Surgeon General, pledged to reduce the nation's high rate of unwanted teen-age pregnancy and the rising adolescent HIV infection rate. To meet this challenge, schools, parents, and others serving youth must address why youth become sexually active early in life and provide the services to postpone early initiation of sexual activity. As evidenced by two recent evaluations, schools and clinics can successfully support young people in postponing intercourse and in being more responsible about sexual activity. ${ }^{22.23}$ Dr. Elders has pledged to advocate for school-based health education and services. She asserts that "school is the only place I know they [adolescents] go" so school-based health education should be the focus of prevention efforts. ${ }^{24}$

\section{References}

1. Centers for Disease Control. Sexual behavior among high school students - United States, 1990. MMWR. 1992;40:885-888.

2. Select Committee on Children, Youth, and Families, U,S, House of Representatives. A Decade of Denial: Teens and AIDS in America.
Washington, DC: US Government Printing Office; $19 \overline{992 .}$

3. Centers for Disease Control. Premarital sexual experience among adolescent women - US, 1970-1988. MMWR 1991;39(51-52,):29-932.

4. Brinton LA, Fraumeni JF. Epidemiology of uterine cervical cancer. J Chronic Dis. 1986;44:199-203.

5. Males M. School-age pregnancy: Why hasn't prevention worked? J Sch Health. 1993;63:429-432.

6. Hayes C, ed. Risking the Future: Adolescent Sexuality, Pregnancy and Childbearing. Washington DC: National Academy Press; 1987.

7. Centers for Disease Control, Division of STD/HIV Prevention, Annual Report 1990. Atlanta, Ga: Centers for Disease Control.

8. Centers for Disease Control. Selected behaviors that increase risk of HIV infection among high school students - United States, 1990. MMWR, 1992;41:231-240.

9. SAS Users Guide: Statistics. Cary, NC: SAS Institute; 1985.

10. Garrison CZ, McKeown RE, Valois RF, Vincent ML. Aggression, substance use and suicidal behavior among high school students. Am J Public Health. 1993;83(2):174-184.

11. Richter DL, Valois RF, McKeown RE, Vincent ML, Correlates of condom use and number of sexual partners among high school adolescents. J Sch Health. 1993;63(2):91-96.

12. Valois RF, Vincent ML, McKeown RE, Garrison CZ. Adolescent risk behaviors and the potential for violence: A look at what's coming to campus. Am J College Health. 1993;41(4);141-147.

13. Dryfoos JG. Adolescents at Risk: Prevalence and Prevention. New' York, NY: Oxford University Press; 1990.

14. Jessor R, Jessor S. Problem Behavior and Psychosocial Development: A Longitudinal Study of Youth. New York, NY: Academic Press; 1977

15. Staples R. The Black Family: Essays and Studies, 2nd ed, Belmont, Calif: Wadsworth; 1978 .

16. Ingram M. Men: The Male Myth Exposed. London, England; Century Press; 1984.

17. Holtzman D, Greene BZ, Ingraham GC, Daily LA, Demchuck DG, et al. HIV education and health education in the United States: A national survey of local school district policies and practice. $J$ Sch Health. 1992;62:421-427.

18. Calamidas EG. Reaching youth about AIDS: Challenges confronting health educators. Health Values. 1991;15:55-61.

19. Ross MW, Caudle C, Taylor J. Relationship of AIDS education and knowledge to AIDS-related social skills in adolescents. $J$ Sch Health, 1991;61:351-354.

20. Kirby D. School-based programs to reduce sexual risk-taking behavior. $J$ Sch Health. 1992;6(27);280-287.

21. Haffner DW. Sex Education 2000: A Call for Action. New York, NY: Sex Information and Education Council of the United States; 1990.

22, Howard M, McCabe JB. Helping teenagers postpone sexual involvement. Fam Plann Perspect. 1990;22:21-26.

23. Zabin LS, Hirsch MB, Smith EA, Street R, Hardy JB. Evaluation of a pregnancy prevention program for urban teenagers. Fam Plam Perspect. 1986;18:119-126.

24. American Public Health Association. Health Care System Neglects Adolescents, Elders Says. Nation's Health. December 1993, p 14.

\section{Statement of Purpose}

The Journal of School Health, an official publication of the American School Health Association, publishes material related to health promotion in school setting5. loumal readership includes administrators, educators, nurses, physicians, dentists, dental hygienists, psychologists, counselors, social workers, rutritionists, dietitians, and other health professionals. These individuals work cooperatively with parents and the community to achieve the common goal of providing children and adolescents with the programs, services, and environment necessary to promote health and to improve learning.

Contributed manuscripts are considered for publication in the following categories: general articles, research papers, commentaries, teaching techniques, and health service applications. Primary consideration is given to manuscripts related to the health of children and adolescents, and to the health of employees, in health service applications. Primary consideration is given to manuscripts related to the health of children and adolescents, and to the heolts
public and private pre-schools and child day care centers, kindergartens, elementary schools, middle level schools, and senior high schools. Manuscripts related to college-age young adults will be considered if the topic has implications for health programs in preschools through grade 12. Relevant international manuscripts also will be considered.

Prior to submitting a manuscript, prospective authors should review the most recent "Guidelines for Authors." The guidelines are printed periodically in the Journal; copies also may be obtained from the Joumal office, P.O. Box 708, Kent, OH 44240. 